\title{
Fluctuating Wind Pressures due to the Conical Vortices on Flat Roofs
}

\author{
Tetsuro TANIGUCHI, Yoshihito TANIIKE and Junko IKEUCHI
}

\begin{abstract}
When an incident flow attacks to structures with a flat roof at an oblique angle, conical vortices are produced on the roof. The severe suctions are appeared near the windward vertex by the conical vortices. In the case of the delta wing, the steady suctions occur because of the stability of the conical vortices. However, the wind pressures on the roof of the box-type structures are fluctuating, differently from the case of the delta wing. This paper presents the flow patterns on the flat roof of several models with a square section by means of a flow visualization with a laser sheet and a strobe light. The characteristics of the fluctuating wind pressures are also investigated by Proper Orthogonal Decomposition(POD). Based on the results of the flow visualization and the POD analysis, the relations of the conical vortices and the fluctuating wind pressures are studied.
\end{abstract}

Keywords: Flow visualization, Conical vortex, Wind tunnel experiment, Flat roof

\section{1.はじめに}

陸屋根面の対角線方向に風が当たる場合、屋根面の風 上側偶角部付近に強い負圧が作用する。これは、デルタウィ ングと同様に、屋根面上に形成される安定した一対の円錐 渦によってもたらされると考えられてきた 1),2)。しかし、 Katsura ${ }^{3}$ ) は立方体模型を用いた風洞実験により、負圧が 強い軸対称な2点に作用する変動風圧について調べ、幾何 学的に対称な条件の下でも、風圧は瞬間的には対称に作用 せず、ほぼ逆の位相をもって変動することを示している。これ は、デルタウイングの場合とは現象が異なることを示唆したも のである。河井ら4)は高さが一辺の $1 / 2$ の模型を用いた風洞 実験により、Katsura と同様の結果を示すとともに、屋根面 に加わる風圧の時系列データを用いた詳細な解析から、風 圧が対称に作用しない原因として、両側の円錐渦が一対と なって振動する、いわゆる'ゆらぎといら現象があると指摘し ている。

本研究では、正方形平面をもつ模型に対して、屋根面対 角線方向に風が当たる場合について、ストロボ装置およびレ 一ザーシートを用いた可視化風洞実験により、屋根面上の 流れの様子、特に円錐渦の挙動について調べる。この際、 屋根勾配を変化させてその影響についても示す。また、可 視化風洞実験と同形状の模型を用いた風圧測定実験を一 様流および勾配流中において行い、屋根勾配とともに接近
流の違いによる風圧特性の変化についても調べる。最後に、 両実験結果を比較することにより、円錐渦の挙動と接近流と の関係や、円錐渦が屋根面の変動風圧に及ぼす影響につ いて考察する。

\section{2. 可視化風洞実験}

\section{1 実験方法}

実験は、大阪市立大学工学部の吹き出し型小型風洞装 置(断面: 幅 $300 \mathrm{mmx}$ 高さ $680 \mathrm{~mm}$ )を用いて行った。気流 は風速 $1 \mathrm{~m} / \mathrm{s}$ の一様流を用いた。なお、床面および側面に 発達する境界層厚さは、ともに $1.5 \mathrm{~cm}$ 程度であり、今回の実 験におよぼす影響は無視できると考えられる。

実験はFig.1に示す 4 種類の模型を用いて行った。 Model-A は、一辺 $100 \mathrm{~mm}$ の立方体であり、壁面はアルミ 製の角パイプ、屋根面にはアクリル板を用い、表面はアクリ ルラッカー(豊消し黒)で塗装を施した。Model-B,Model-C は Model-A と同じ平面形状で、それぞれ風下, 風上側が低 くなっている。Model-D は一辺 $100 \mathrm{~mm}$, 厚さ $5 \mathrm{~mm}$ の平板 状で、 $4 \mathrm{~mm}$ の真鍮角材と厚さ $0.5 \mathrm{~mm}$ の真鍮薄板を用い て制作した。各模型の内部は、煙溜 (Mist Box) とつながっ ており、屋根面の風上側稜線部付近に、幅 $1.5 \mathrm{~mm}$ のスリッ 卜を設けた。なお、模型の一辺の長さを代表長さとした場合 のレイノルズ数は、 $6.85 \times 10^{3}$ である。

次に、実験方法についてFig.2をもとに以下に示す。まず、 
ミスト発生装置(Mist Generator)を用いて、脱イオン水・プロ ピレングリコールおよびグリセリンからなる専用リキッドを加熱 することによりミストを発生させる。ミストを煙溜に送り込み、一 定時間後にミスト発生装置を煙溜から離す。煙溜と模型内部 に溜まったミストは、模型屋根面に加わる負圧により、模型に 設けたスリットから風洞内に吸い出される。これによって屋根 面上の流れの様子を観察する。

この方法の特徵は、模型内部を煙溜の一部として使用し た点である。従来の可視化実験では、模型外部からミストを 風洞に送り込む方法、あるいは模型表面に薬品を塗布し化 学反応によりミストを発生させる方法等が用いられてきた。こ れらの方法では、注目する部分以外にもミストが流れ、現象 がとらえにくい場合がある。本論文で対象としたような、流れ が剥離する箇所が決まっている現象の場合、今回示した一 定の箇所からミストが流出する方法は有効であると考えられ る。また、コンプレッサー等を用いず、屋根面に加わる負圧 によってミストを流出させるため、風洞流を乱すことなく実験 が行える。さらに、煙溜を設けたことにより、比較的長い時間 の観察が行えることも特徵の一つであるといえる。今回用い た煙溜の大きさでは、ストロボ光やレーザーシートを用いた 場合で 10 分程度、通常の室内光のもとでも5分程度の継続 した可視化が可能である。

記録システムをFig.3に示す。Video Camera により撮影 したビデオ画面毎に Frame Counterによって番号を記録 し、Video Recorderで録画した。なお、Frame Counter によるカウントは $1 / 60$ 秒間隔で、Video Recorder も 1/60 秒間隔でのコマ送り再生が可能である。

実験は、ストロボ装置およびレーザーシートをそれぞれ用 いて行った。ストロボ装置は模型の斜め前方の屋根面よりや や高い位置に設置し、ビデオのコマ送りに合わせて約 $60 \mathrm{~Hz}$ で発光させた。光量が、ピーク值の $1 / 2$ に達してから $1 / 2$ に 落ちるまでの時間(閃光時間) は、 $35 \mu \mathrm{sec}$ 以下である。

\section{2 実験結果}

Fig.4に Model-A の結果を示す。図の上段はストロボ装置 を用いた屋根面上の流れを、下段はレーザーシートを用い た流れの断面を示している。なお、上・下段の図は同時に得 られたものではなく、それぞれの場合に対応すると考えられ る図を選んだ。

左上段の図では、風下からみて左側 (写真の下側)に風 上側頂点からのびる円錐渦がみられる。風上側頂点付近に 注目すると、渦の中心線に対しミストが螺旋状に巻き込まれ ている様子が確認できる。下段の断面をみると、片側にのみ 円錐渦が存在することがわかる。やがて中央の図に示す対 称な状態 (平衡状態) となる。この状態は過渡的なもので、す ぐに元の状態、もしくは右の図に示すように円錐渦が反対側 に現れる状態となる。これらの現象は、おおむね交互に起こ っているが、明確な周期性はみられなかった。以後、この現 象を"スイッチング現象"と呼ぶ。

Fig.4の左右の断面を比較すると、それぞれの円錐渦の状 態は異なっている。すなわち、左図では、円錐渦は緩やかに

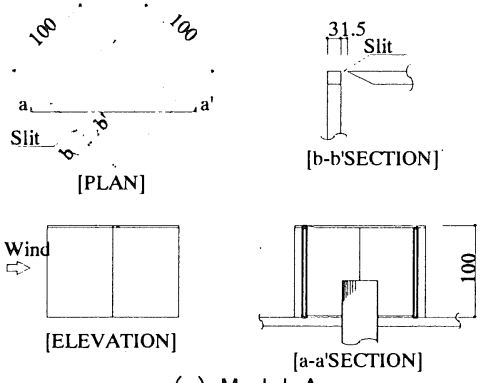

(a) Model-A

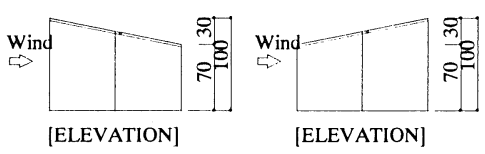

(b) Model-B (c) Model-C
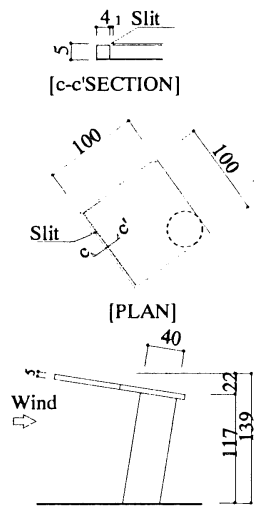

[ELEVATION]

(d) Model-D

Dimensions in $m$
Fig.1 Visualization model

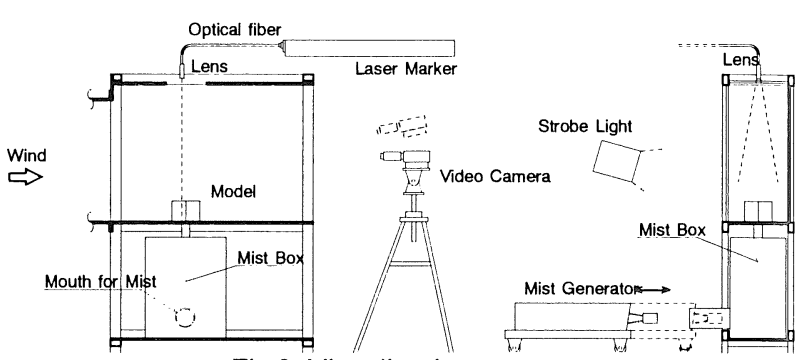

Fig.2 Visualization setup

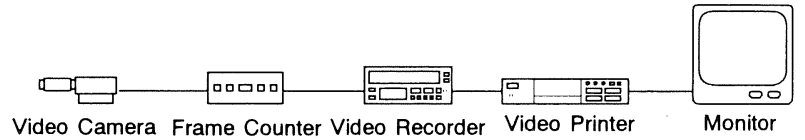

Fig.3 Recording system
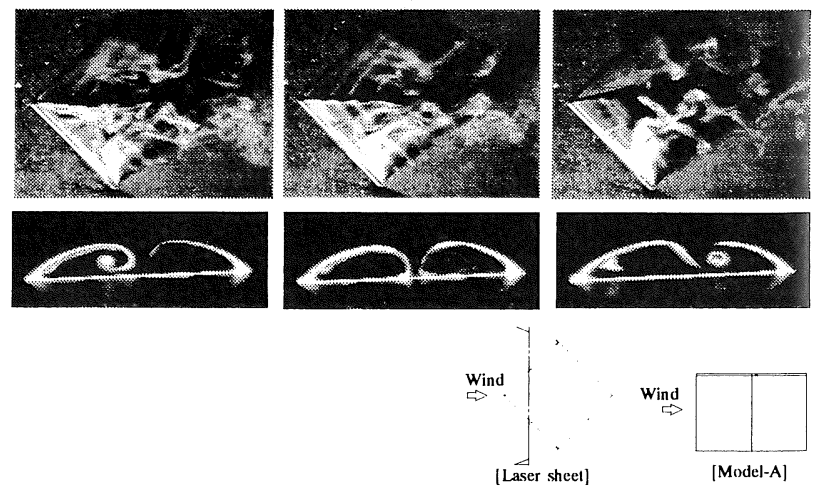

Fig.4 Flow pattern on the roof(Model-A)

巻き込まれており、その中心位置は風上側稜線から遠い位 置にある。右図では、円錐渦の半径は小さく、またその中心 位置も風上側稜線に近づく。右上段の図からも、円錐渦が 風下方向に引き延ばされている様子がうかがえる。ランキン 渦を仮定すれば、循環が一定である場合、渦の中心圧は半 径の2乗に反比例して下がることから 5 )、円錐渦が引き延ば され、その半径が小さくなることにより、屋根面の圧力も降下 するものと考えられる。 
Fig.5に Model-B,C,D の結果を示す。なお、レーザーシー トの位置は Model-A と同様である。 Model-B は、風上側 が高く、立方体(Model-A)の場合と同様に、円錐渦はスイッ チング現象を示す。ただし、円錐渦は屋根面からやや離れ た位置にみられる。Model-C は、風上側が低いため、稜線 部ではく離した流れが屋根面に再付着し、一対の円錐渦が みられる。ただし、これらの渦は左右に小さく振動しており、 河井ら 4)の指摘した'ゆらぎといら現象ではないかと考えられ る。Model-D は屋根面のみの場合であり、角度はやや小さ いものの、Model-B と同様風上側が高い。しかし、稜線では く離した流れは屋根面に再付着し、一対の円錐渦を形成す る。ただし、Model-B と異なり、この円錐渦は安定している。

\section{3. 多点同時風圧測定実験}

\section{1 実験方法}

実験は、大阪市立大学工学部のエッフェル型風洞(断面: 幅 $1,000 \mathrm{~mm} \times$ 高さ $1,000 \mathrm{~mm}$ )を用いて行った。実験気流 には、風速 $10 \mathrm{~m} / \mathrm{sec}$ の一様流と勾配流を用いた。

模型は、可視化風洞実験に用いた Model-A および Model-C と同形状であり、各模型には、屋根面 34 点、風上 側側面各 27 点、および風下側側面各 4 点の計 96 点の風 圧測定孔を設けた。

実験では、模型頂部相当高さの風速とともに、模型に作 用する風圧を、風洞内に設置したピトー静圧管による静圧と の差圧として測定した。サンプリング周波数は $500 \mathrm{~Hz}$ で、デ 一夕個数は 8,192(16.384 秒)である。

\section{2 固有直交関数展開(POD解析)}

変動風圧の組織的な構造を調べる場合、固有直交関数 展開(POD 解析 6)) は有効である。POD 解析では、各点に 作用する変動風圧を要素とする時系列べクトルを、空間相関 行列を用いた固有値解析により得られたモードを用いて展 開する。このとき、特に低次のモードは、全体の変動エネル ギーに対する寄与率が高いことから、何らかの物理的な意味 を持つことが期待される。

Fig.6に一様流の場合の各模型についての1次および2次 の固有モードを示す。図では負の值は面の色で示し、正の 值については等值線で示した。なお、図中の数値は全体の 変動風圧のエネルギーに対する各モードの寄与率である。

図の示す意味について、立方体模型 Model-A の2次モ 一ドを用いて説明する。このモードは、風上側壁面がほぼ一 様に正であり、屋根面は負の值を示す。これは、風上側壁面 の風圧が増加する場合、屋根面の風圧が低下する風圧変 動を示している。したがって、このモードは接近流速の変動 に伴う、準静的な風圧変動を表しているものと考えられる。ま た、屋根面の分布形状から、円錐渦の影響を読みとることが できる。

本研究で対象とする円錐渦の挙動に伴う変動風圧を考え る場合、1次モードの方が興味深い。このモードは、屋根面 および風上側壁面において、風向方向の対角線にほぼ逆 対称な分布を示す。また、風上側壁面の係数の絶対值が屋
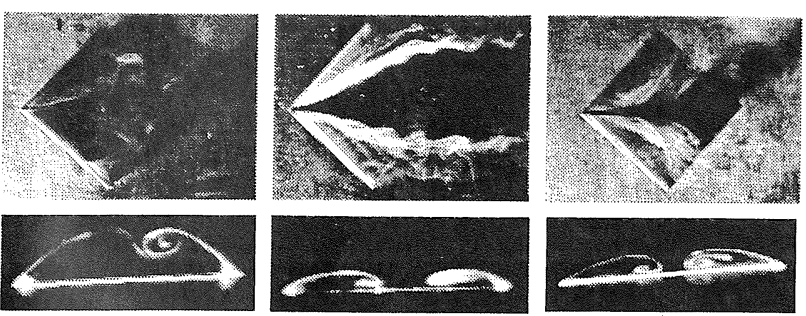

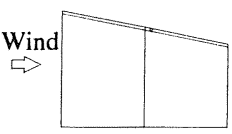

(a) Model-B

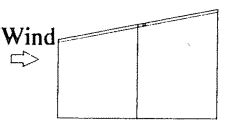

(b) Model-C
$\underset{\Longleftrightarrow}{\text { Wind }}$

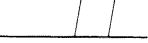

(c) Model-D
Fig.5 Flow pattern on the roof(Model-B,C,D)

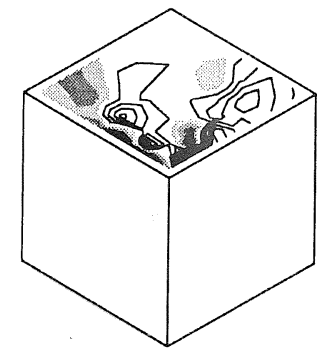

(a) Model-A(1st 59.4\%)

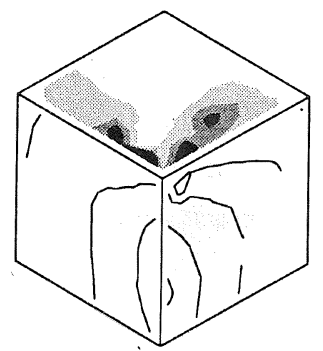

(b) Model-A(2nd 12.5\%)

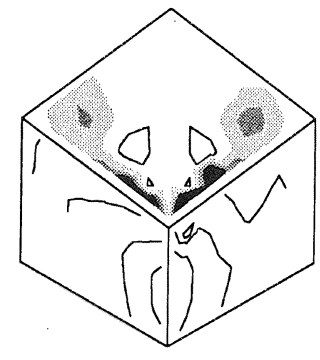

(c) Model-C(1st 32.3\%)

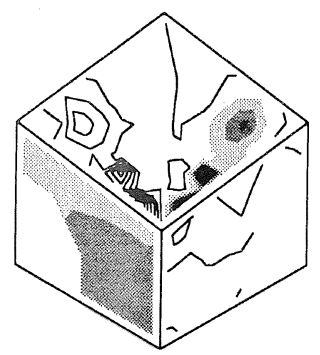

(d) Model-C(2nd 22.6\%)

Fig.6 Eigenvectors of pressures(smooth flow)
根面に比べて小さいことも特徴的である。

風上側が低い Model-C の場合、1次モードは準静的な成 分を表している。また、2次モードは円錐渦の影響による成 分であると考えられるが、Model-A の1次モードに対して、 屋根面と壁面との関係に以下のような違いがみられる。この モードを詳細にみると、Model-C の右側壁面の風圧が増加 する場合、屋根面右側の風上側稜線部付近の風圧が低下 する。Model-A の場合、右側壁面の風圧が増加する場合、 図では明確ではないが、屋根面右側の風上側稜線部近傍 の風圧は増加し、反対に左側の稜線部付近の風圧が低下 する。可視化風洞実験によれば、Model-A の場合には、円 錐渦が1つだけ形成され、スイシチング現象がみられた。一 方、風上側が低いModel-C の場合には、1対の円錐渦が形 成され左右に振動する、ゆらぎという現象がみられ、変動風 圧場の違いは、それぞれの場合における、円錐渦の性状の 違いに起因するものと考えられる。この点について、次節で 詳しく考察する。 
Fig.7に、勾配流の場合の固有モードを示す。これらは、模 型の形状に関わらず、1次モードは屋根面および風上側壁 面で、風向方向の対角線にほぼ逆対称であり、勾配流中に おける Model-C の場合とほぼ同様の分布形状を示す。ま た、ここでは示していないが、模型の形状によらず、2次モー ドは準静的な変動成分を表していた。

\section{4. 円錐渦之変動風圧の関係}

POD 解析により得られた、円錐渦の挙動に伴う変動風圧 成分は、Fig.8の2つのタイプに分類できる。この図では、黒い 部分と白い部分が互いに逆位相で変動していることを示して いる。Type-A は、一様流中における立方体模型 Model-A の場合にみられたモードであり、Type-B は、一様流中の Model-C および勾配流中での両模型についてみられたモ 一ドを示している。それぞれについて、可視化風洞実験結果 を含めて考察し、屋根面上に形成される円錐渦による変動 風圧特性について示寸。

\section{1 円錐渦のスイッチング現象による風圧変動}

Type-A は、右側壁面 A2 の圧力が上昇する場合には、 左側壁面 $\mathrm{A} 1$ と屋根面 $\mathrm{A} 3, \mathrm{~A} 5$ の部分の圧力が低下するモ ードである。ここでは示せなかったが、このモードに対応する 規準座標は、その長周期成分が卓越しており、大規模な流 れの変化、すなわち円錐渦のスイッチング現象による風圧変 動を示していると考えられる。可視化風洞実験結果から、右 側壁面 A2 の圧力が上昇する場合には、円錐渦は屋根面 A5 上部に存在し、この部分の圧力低下は円錐渦によっても たらされると考えられる。このとき、円錐渦は、左側稜線から の剥離流を引き込む。そのため、剥離流の流速が増加し屋 根面 A3 部分の圧力も低下するものと考えられる。また、左 側壁面 $\mathrm{A} 1$ の圧力が上昇する場合には、円錐渦は A4 の上 部に移り、屋根面 $\mathrm{A} 4$ および $\mathrm{A} 6$ 部分の圧力が低下寸ると考 えられる。

\section{2 一対の円錐渦による風圧変動}

Type-B も、Type-A と同様に屋根面が4つのエリアに分 かれるモードである。ただし、壁面と屋根面の関係が Type-A とは異なり、右側壁面 B2 の圧力が上昇する場合に は、左側壁面 B1 と屋根面 B4,B6 部分の圧力が低下する。 このモードは、一様流中での風上側が低い Model-C で高い 寄与率を示す。この場合、可視化風洞実験から、一対の円 錐渦が、B4 および B6 の上部に存在すると考えられ、これ らの部分の圧力低下は円錐渦によってもたらされたと考えら れる。また、勾配流中では模型によらず、このモードが高い 寄与率を示しているが、これは接近流の乱れにより、はく離 流が再付着しやすくなり、立方体模型 Model-A の場合に も、一対の円錐渦が形成されるためであると考えられる。

右側壁面 B2 の圧力が上昇すると、屋根面 B6 上の円錐 渦の強度は増し、その中心圧力は低下し、その影響で屋根 面 B6 部分の圧力が低下する。また、渦の半径が小さくなる 場合、中心圧力も低下していると考えられるが、可視化風洞 実験ではこのような場合、円錐渦が風上側稜線方向に引き

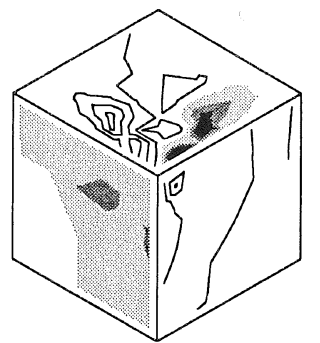

(a) Model-A(1st 29.9\%) Fig.7 Eigenvectors of pressures(turbulent flow)

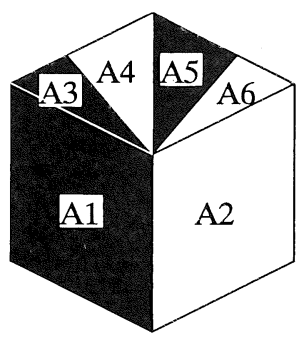

Type-A (b) Model-C(1st $36.1 \%)$
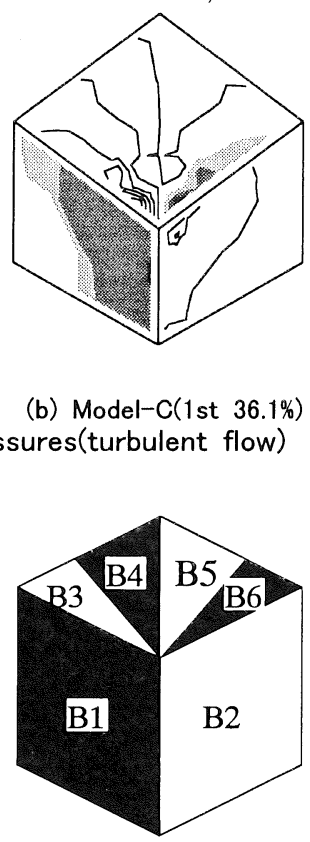

Type-B
Fig.8 Fluctuated pressure pattern

寄せられることが確認された。その結果、再付着位置も風上 側に移動し、屋根面 B5 の圧力が上昇すると考えられる。

\section{5. おわりに}

正方形平面をもつ陸屋根構造物が、対角線方向に風を 受ける場合、屋根面上には円錐渦が形成される。本研究で は、屋根勾配の異なる模型を用いた可視化風洞実験により、 屋根面上の円錐渦がどちらか片方にだけ存在し、交互にそ の位置を変える、スイッチング現象について示した。また、風 圧測定実験を基に、変動風圧の組織的な構造を POD 解析 により調べ、スイッチング現象を含む円錐渦の性状と、それ に伴う屋根面の変動風圧特性の関係について示した。

\section{参 考文 献}

1) Prenel,J.P.,Porcar,R., El Rhassouli,A.: Three Dimensional Flow Analysis by Means of Sequential and Volumic Laser Sheet Illumination, Experiments in Fluids, Vol.7, pp.133-137, 1989.

2) Kramer,C., Gerhardt,H.J.: Wind Pressures on Roofs of Very Low and Very Large Industrial Buildings, Journal of Wind Engineering and Industrial Aerodynamics, Vol.38, pp.285-295,1991.

3) Katsura,J.: A Wind Tunnel Test of Pressure Distributions on Box-Shaped Models, Proc. of USA-Japan Research Seminar Wind Loads on Structures, pp.97-108,1970.

4）河井宏允,西村元吾,草柳拓人: 陸屋根上の円錐渦と負圧変動 について，第 13 回風工学シンポジウム論文集，pp.149-154， 1994

5) 日野幹雄: 流体力学, 朝倉書店, 1992.

6）田村幸雄: 固有直交関数展開のランダム変動場への応用のす すめ, 日本風工学会誌, No.65, pp.33-41, 1995.10

7) Bienkiewicz,B.: Proper orthogonal decomposition of roof pressure, Proceedings of Bluff Body Aerodynamics, 1992. 